\title{
研究報文
}

\section{新たに開発したホーラーがアスパラガスの定植における 作業性に及ぼす影響}

清水 佑 $*$. 松永邦則 **・浦上敦子 *** · 柘植一希 * - 山口貴之 $* * * *$ 元木 悟*

*明治大学農学部, **パイオニアエコサイエンス株式会社,

***農研機構野菜茶業研究所, ****岩手県農業研究センター

Effects of a Newly Developed Hole-Maker on the Efficiency of Planting Asparagus

\author{
Tasuku SHIMIZU*, Kuninori MATSUNAGA**, Atsuko URAGAMI***, Kazuki TSUGE*, \\ Takayuki YAMAGUCHI**** and Satoru MOTOKI* \\ *Agricultural department of Meiji University \\ **Pioneer Ecoscience \\ ***Tsukuba Vegetable Research Station, NARO Institute of Vegetable and Tea Science \\ **** Iwate Agricultural Research Center
}

\begin{abstract}
著者らは，アスパラガスの定植において，七ル成型苗からポット苗への鉢上げせずに，七ル成 型苗を直接围場に定植する新たなホーラーを開発した。アスパラガスの伏せ込み促成栽培におい て，そのホーラーを用いてセル成型苗のまま直接围場に定植する新規法と，慣行のホーラーを用 いてポット苗を定植する慣行法とを比較し，定植作業の改善効果とアスパラガスの収量の指標と なる株養成量を調査した。 その結果，新規法は，慣行法に比べて，初心者，習熟者ともに，アス パラガスの定植作業時間が有意に短縮された。OWAS 法を用いた作業姿勢の評価では， $\mathrm{AC}$ (ア クションカテゴリー）の発生回数㧍よび発生割合の結果から，習熟者においては，新規法が慣行 法に比べてアスパラガスの定植作業姿勢を改善できた。一方，初心者においては，ACの発生割 合で定植作業姿勢の改善効果が見られなかったものの, ACの発生回数では改善効果が見られた. アスパラガスの定植作業時間が短縮されたことを考慮すると，初心者においても，新規法が慣行 法に比べて作業負担は低いものと考えられる。 また, 株養成量では, 新規法は, 慣行法に比べて, 育苗日数が短く，小さなセル成型苗を定植したにも関わらず，新規法と慣行法との間に有意差が なかったことから，ポット苗を定植する慣行法と同等の収量が得られるものと考えられた．

キーワード: アスパラガス, 作業性, セル成型苗, 定植, ホーラー
\end{abstract}

\section{1. 緒言}

現在，日本の農業における問題として，農業従

2015 年 1 月 22 日受付

2016 年 1 月 30 日受理

Corresponding author

元木 悟 Satoru МотокI

干 214-8571 神奈川県川崎市多摩区東三田 1-1-1

1-1-1 Higashimita, Tamaku, Kawasaki-city, Kanagawa, Japan

E-mail : motoki@meiji.ac.jp
事者の高齢化，農業就業人口の減少，新規就農者 の減少や後継者不足などが挙げられる。1985 年 から 2010 年にかけて, 65 歳以上の基幹的農業従 事者の割合は $19.5 \%$ から $61.1 \%$ に増加し（農林 水産省 2013), 農業就業人口も 543 万人から 261 万人に減少した（農林水産省 2013）。また, 新規 就農者数は 2007 年から 2013 年にかけて, 73,460 人から 50,810 人に減少し, 年度によって多少の 増減はあるものの, 年々減少傾向にある（農林水 
産省大臣官房統計部 2014）。午の原因の 1 つとし て, 農業は $6 \mathrm{~K}$ （きつい, 污い, かっこ悪い, 臭 い, 稼げない，結婚できない）と言われ（但馬 県民局 2012)，実際に新規就農者となりうる若者 が, 農業に対して重労働であるというイメージを 持つと報告がされている（中央農業総合研究セン ター1995)。また, これからの農業に必要な条件 の中で「軽作業程度の労働であること」が全体の $43.6 \%$ 占め, 最も高い值となっており，作業環 境改善として作業姿勢の改善も挙げられている （農林水産省 2006，2009）.

ところで，一般に重労働とされる看護や工業の 現場では, 多くの作業性に関する調査が行われ, 作業姿勢の改善がなされている（Karhu ら 1981, Takala and Kukkonen 1987).

作業性に関する調査は，農業においても長時間 の作業が必要となるブドウなどの果樹栽培（八巻 ら 1993, Yin ら 2012) やイチゴなどの高設栽培（前 川ら 2000, 宮䇂・片岡 2004）などで行われてお り, 作業負担の少ない姿勢, 作業時間を短縮する ための機械や器具の開発および作業負担を軽減で きる栽培体系の開発が多くの生産現場で求められ ている. 作業時間や作業効率に関する研究（有馬 ら 1995, 渋川ら 2014）がある中で, 作業負担や 作業姿勢など身体的な観点に着目した研究も行わ れている（藤原ら 2006, 大石ら 2010)。作業負担 としては心拍数や脳波, 筋電位などが測定され評 価されている（石川・小林 1999）。作業姿勢に関 しては, $8 \mathrm{ch}$ 姿勢解析システムや姿勢区分評価法, Ovako 式作業姿勢分析システム（以下, OWAS 法) などで評価が行われており（石川・小林 1999 , 宮訔・片岡 2004), 本研究ではその中の OWAS 法を用いて調查した。 OWAS 法は, フィンラン ド労㗢衛生研究所が開発した作業姿勢分析ソフト を用いる評価法であり（Karhu ら 1977），建築作 業や貨物運搬作業など， 20 種以上の様々な分野 で研究に用いられている（瀬尾 1995）。本手法は, 観察者が異なっても, 結果の一致率が $90 \%$ 以上 と高い再現性を有し, 特別な機械や能力を用いな くとも調査が可能であることから，多くの分野で 利用されている（瀬尾 1995）.

本研究で取り扱うアスパラガス (Asparagus offcinalis L.) は, キジカクシ科アスパラガス属に 属する植物であり, 野菜では珍しい多年生の植物 である（元木 2003）。アスパラガスは, 前年の光

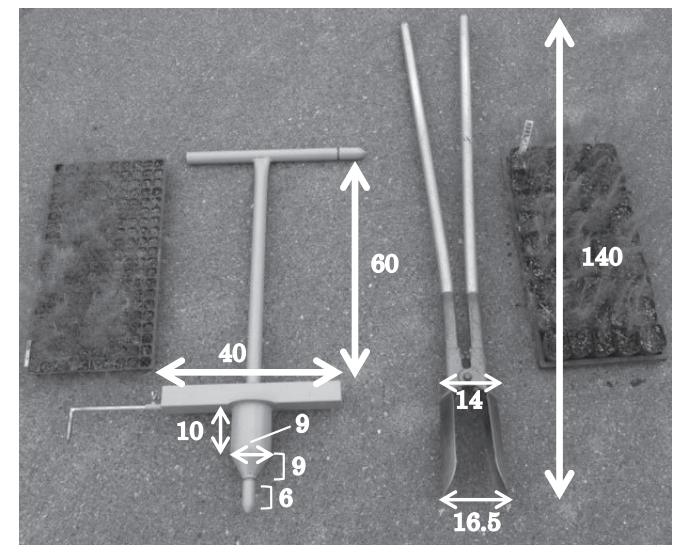

図 1 本研究に用いたホーラーの比較 左が新たに開発した新規ホーラー, 右が慣 行ホーラー。

規格の単位は $\mathrm{cm}$.

合成産物が貯蔵根へ蓄積され, 翌年の春季に萌芽 する若茎を収穫する。この時, 貯蔵根の量と貯蔵 根に蓄えられた養分量（株養成量）が若茎の収穫 量に影響するため, 高収量を目指す際に重要な指 標となる（元木 2003, 酒井ら 1991）。近年では単 価の高くなるクリスマスや年末に向けてアスパラ ガスを出荷するため, 群馬県や東北地方を中心に 伏せ込み促成栽培が行われている（地子ら 2008, 小泉 2007, 武田・本庄 2005). 伏世込み促成栽培 とは, 春から秋にかけて露地で根株を養成し, 晚 秋に掘り上げた根株をハウス内に持ち込んで加温 を行うことにより, 萌芽を促進させて収穫を行う 栽培体系であり, 若茎があまり流通していない冬 季に収穫することができる（武田・本庄 2005）.

セル成型苗直接定植は一般的にキャベッなど の葉菜類の栽培で広く用いられており（吉岡 2007), ポットへ鉢上げする二次育苗を省略でき るため, 育苗時間の短縮, 育苗面積の縮小扔よび 資材コストの削減などが期待できる，そのため, 省力・低コストの観点からポット苗定植が広く利 用されているトマトやカボチャなどの果菜類の栽 培でも, セル成型苗直接定植の導入が検討されて いる（金子・鈴木 2002 , 根岸 ·大島 2009 , 杉山 ら 2006).

一方, 上記のアスパラガスの伏せ込み促成栽培 では, 秋季の根株の掘り上げ時に高収量のための 大株養成が期待できないことから, 七ル成型苗は 定植に用いられておらず（山口ら 2013），4月下 

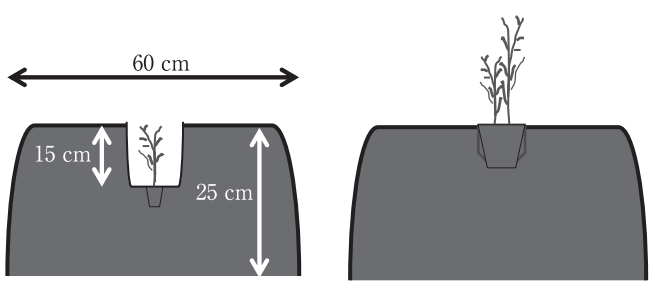

図 2 新規法および慣行法における定植の比較 左が新規ホーラーによるセル成型苗の直接 定植.

右が慣行ホーラーによるポット苗の直接定植.

旬頃から 5 月中旬頃に，七ル成型苗を鉢上げした ポット苗を, ホーラー（図1右：以下, 慣行ホー ラー）を用いて作成した植穴に定植している（小 泉 2007)。 そこで著者らは, アスパラガスの伏せ 込み促成栽培に扔いても, 葉菜類や果菜類と同じ 上記メリットを得るために，セル成型苗を（ポッ ト苗に鉢上げせずに）そのまま直接深植えできる ホーラーを新たに開発した（図 1 左：以下，新 規ホーラー)，新規ホーラーは，七ル成型苗を 15 $\mathrm{cm}$ 程度の深植えにする形状をとり（図 2), 深植 えによる（植穴内の保温効果による）生育促進効 果が期待できる.ささら, 新規ホーラーは慣行ホー ラーに比べて，地面に突き刺す動作のみで容易に 植穴を作成できるため, 定植作業の省力効果も期 待できる。

一方で, 前述のとおり, 日本に㧍ける新規就農 者数は減少しており, 重労働と捉えられる農作業 のイメージを改善し, 新たな担い手の就農を増や すため, 新規就農者を意識した作業性の改善に関 わる試験も必要であると考える.

そこで本研究では, 新規ホーラーを用いてセル 成型苗のまま直接定植する新規法と慣行ホーラー を用いてポット苗を定植する慣行法を, 伏せ込み 促成栽培の作型において比較するとともに, 被験 者として, 作業に熟練した習熟者 1 名と, 作業に 熟練しておらず，新規就農者となり得る初心者 1 名の熟練度の異なる作業者に扔ける定植作業の改 善効果を調査した。

さらに, 新規ホーラーを用いた定植による収量 への影響を確認するため, アスパラガスの収量の 目安となる株養成量を調べることにより，アスパ ラガスの定植における新規法導入の可能性を検討 した.

\section{2. 材料および方法}

1) 栽培条件

試験は，群馬県沼田市の現地戋場で行った，供 試品種は, 伏せ込み促成栽培に適するとされる ‘太宝早生'（パイオニアエコサイエンス）（地子 ら 2011, 皆川ら 2013）とした。栽植様式は, 畧 間 $140 \mathrm{~cm}$, 株間 $40 \mathrm{~cm}$ の 1 条植え（栽植密度： 1,786 株 $/ 10 \mathrm{a} ）$ とした。畧は幅 $60 \mathrm{~cm}$, 高さ 25 $\mathrm{cm}$ であった。現地で慣行として用いられている 黒色の KOB マルチ（みかど化工社製，KOB-20 135）㧍よび北海道や東北地方の生産現場などで 保温効果が見込めるという理由で普及が進んで いる緑色のグリーンマルチ（積水フィルム社製, HF135FK）（元木 2008）の異なる 2 種類のマルチ を土壤表面に被覆した，2種類のマルチの区をそ れぞれ 3 站ずつ作成し, 乱塊法を用いて処理区を 設定した。慣行法では 96 日間育苗した $7.5 \mathrm{~cm}$ 径 のポット苗, 新規法では 72 日間育苗した 200 穴 のセル成型苗を定植した。供試作型は伏せ込久促 成栽培とし， 2013 年 4 月 21 日に定植し，株養成 した根株を同年 11 月 16 日に掘り上げた。基肥 として $\mathrm{N}-\mathrm{P}_{2} \mathrm{O}_{5}-\mathrm{K}_{2} \mathrm{O}$ を 22-23-20 kg/10 a 施用し, 追肥として 5.6-5.6-5.6 kg/10 a, 6.8-0-6.4 kg/10 a, 0-6.8-6.4 kg/10 a を 7 9 月にかけて施用した. その他の栽培管理は, 現地の慣行に準じた。

\section{2）定植作業時間の比較}

慣行ホーラーおよび新規ホーラーを用いて定植 作業時間の比較を行った。いずれのホーラーも鋼 材で構成されており，慣行ホーラーの仕様は全長 $140 \mathrm{~cm}$, 先巾 $16.5 \mathrm{~cm}$, 肩幅 $14 \mathrm{~cm}$, 質量 $4.5 \mathrm{~kg}$ (OWL 社製)（図 1 右），新規ホーラーの仕様は全 長 $90 \mathrm{~cm}$, 縦支柱部の長さ $60 \mathrm{~cm}$, 横支柱部の長 さ $40 \mathrm{~cm}$, 円筒部の長さ $10 \mathrm{~cm}$ および直径 $9 \mathrm{~cm}$, 円錐部の長さ $9 \mathrm{~cm}$, 先頭部の長さ $5.5 \mathrm{~cm}$ (先頭 部は付け替え可能), 質量 $4.3 \mathrm{~kg}$ であった(図 1 左). 定植時に, 全作業工程を, デジタルカメラを用い て動画を撮影した。被験者は, 定植作業に熟練し た 46 歳男性（以下, 習熟者）と定植作業に熟練 していない21歳男性（以下, 初心者）とした。 習熟者は身長 $163 \mathrm{~cm}$, 体重 $60 \mathrm{~kg}$, 作業経験 17 年で, 初心者は身長 $164 \mathrm{~cm}$, 体重 $63 \mathrm{~kg}$, 作業経 験 2 年である. 被験者には数 $\mathrm{a}$ 作業してもらい, その映像から，ホーラーによる植穴作成（図 3 ) 

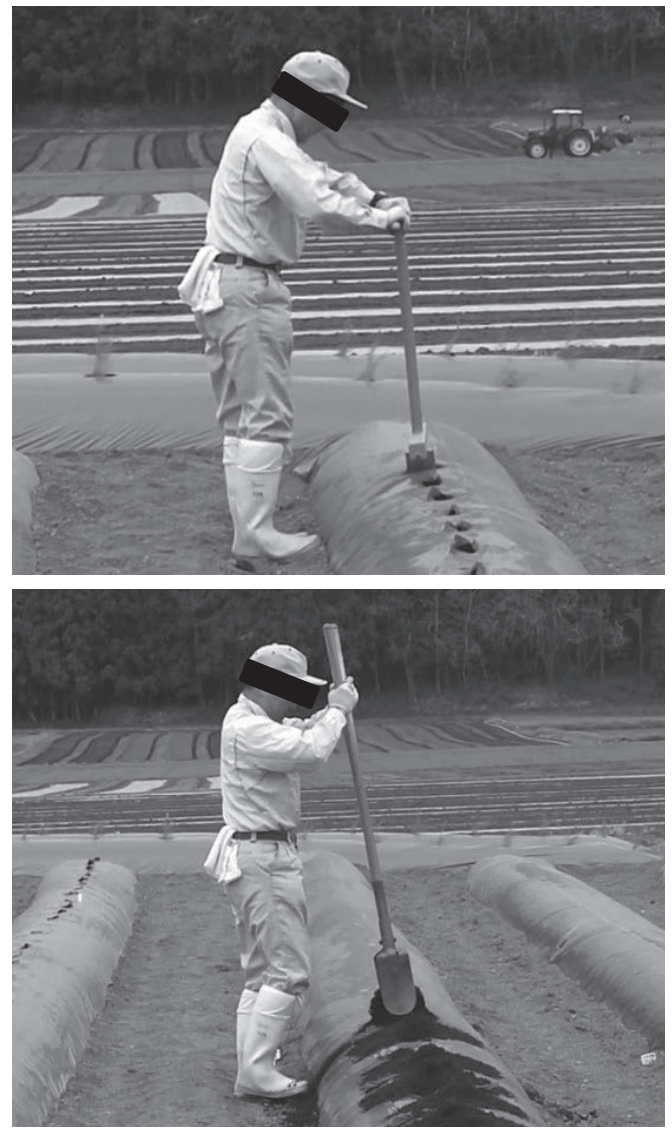

図 3 習熟者による植穴作成の様子 上が新規法，下が慣行法。

新規法は新規ホーラーを地面に突き差す動 作，慣行法は慣行ホーラーを用いて畧内の 土をつかんで外に放出する動作。

と苗の定植（図 4）の時間を定植作業時間として 計測し， 5 株の作業時間 4 反復分を分析して， 1 株当たりの定植作業時間の平均值を算出した，統 計処理は, $\mathrm{t}$ 検定により異なる定植方法間の有意 差を分析した。

\section{3）OWAS 法を用いた定植作業姿勢の比較}

アスパラガスの定植時に打ける作業姿勢は, Karhu ら（1977）が開発した OWAS 法を用いて, アクションカテゴリー（以下，AC）による分類 と評価を行った，2）と同様，定植時の全作業工 程を、デジタルカメラを用いて動画を撮影した. 被験者は，2）と同様の習熟者および初心者とし た。一般的に OWAS 法では, 動画から作業姿勢 を 1 回当たり 30 秒または 1 分間隔で抽出する(瀬
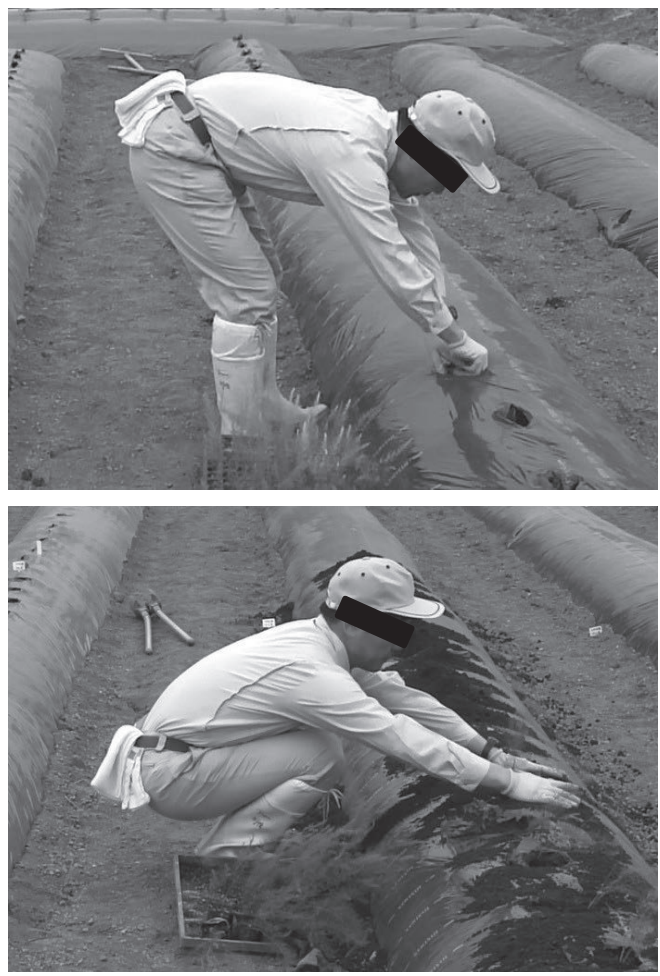

図 4 習熟者による定植の様子 上が新規法, 下が慣行法.

尾 1995）。しかし, 沢田・羽根（2002）は, 通常 の 30 秒間隔とその 3 分の 1 に当たる 10 秒間隔 では AC の発生構成比に顕著な違いが見られない ことを報告した。 また, 坂本ら（2011）は, アス パラガスの若茎の収穫に扔ける作業姿勢を 1 回当 たり 2 秒間隔で抽出し, 評価した。本研究では, 1 株における定植の作業性に着目したため, さら に測定間隔を短くする必要があると考え, 坂本ら （2014）の報告と同様，1回当たり 1 秒間隔で抽 出し, 評価した。撮影した動画から 1 秒ごとの作 業姿勢を抽出し, OWAS 姿勢コード表の背部, 上 肢, 下肢および支持する質量または力の 4 項目を, 坂本ら（2011）の方法に従って4 段階の作業負担 度 $[\mathrm{AC} 1$ : 改善不要（この姿勢による筋骨格系負 担は問題ない), AC2: 近いうちに改善すべき（こ の姿勢は筋骨格系負担に有害である), AC3：で きるだけ早期に改善すべき（この姿勢は筋骨格系 負担に有害である), AC4:ただちに改善すべき(こ の姿勢は筋骨格系に非常に有害である)にに分類 し, 定植作業姿勢の評価を行った。なお, 新規ホー ラー, 慣行ホーラーともに質量が $10 \mathrm{~kg}$ 未満であ 


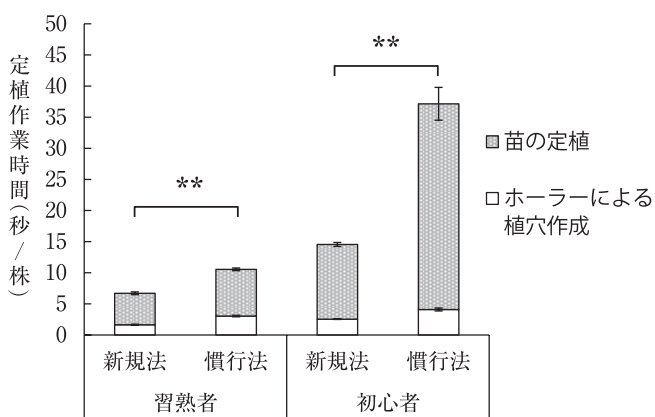

図 51 株当たりの新規法および慣行法における 習熟者掠よび初心者の定植作業時間の比較 5 株の定植作業を 1 反復とし, 4 反復調査 した $(\mathrm{n}=4)$.

エラーバーは標準誤差を示す。

**は $\mathrm{t}$ 検定において $1 \%$ 水準で有意差あり を示す。

り，慣行ホーラーで喃に植穴を開けた際に放出し た土の質量とホーラーの合計の質量も $10 \mathrm{~kg}$ 未満 であったため，支持する質量または力の項目を $10 \mathrm{~kg}$ 未満として評価した。 2) と同様，5株を定 植する間の作業姿勢を測定し，1株当たりの定植 作業姿勢の平均值 $(\mathrm{AC} 1 \sim 4$ の発生回数揖よび発 生割合の平均の值）を算出した５株の定植作業 を 1 反復とし， 4 反復調査した。統計処理は, 作 業姿勢（AC）のデー夕において正規性が確認さ れなかったため, ノンパラメトリック手法である $\mathrm{U}$ 検定により異なる定植方法間の有意差を分析し た。

4）栽培法の違いによる苗質の評価および株養成 量の比較

定植時における苗質の評価と新規法および慣行 法で栽培した株養成量の比較を行った。苗質の評 価は, 2013 年 4 月 21 日の定植時に用いた苗の茥 長 $(\mathrm{cm})$, 根長 $(\mathrm{cm})$, 茎数 (本), 地上部抒よび 地下部それぞれの生体重（g）㧍よび乾物重（g) について中庸な 5 個体を選び計測した。株養成 量は, 2013 年 11 月 16 日に根株を掘り上げした 後に水で洗浄し，生体重を当日に測定した。掘 り上げ後の根株は冷蔵で明治大学生田キャンパ 又（神奈川県川崎市）に輸送し，到着後に貯蔵根 の Brix 值（º）を測定した。貯蔵根の Brix 值は 北澤ら（2012）の方法に従って, 貯蔵根を $-20^{\circ} \mathrm{C}$ の冷凍後に融解して軟化させてから屈折式糖度計

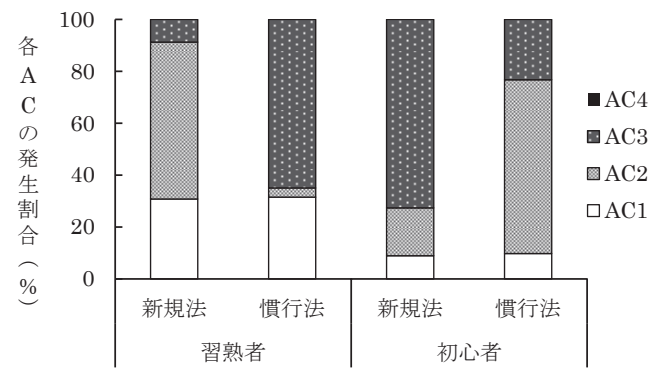

図 6 新規法および慣行法における習熟者および 初心者の各 $\mathrm{AC}$ の発生割合の比較

5 株の定植作業を 1 反復とし, 4 回の平均 值を示す $(\mathrm{n}=4)$.

（PR-1，ATAGO 社製）により測定した，株養成 量は, 元木ら（2006）の方法に従って, 根株の生 体重と貯蔵根のBrix 值の積として算出した。 10 株を 1 反復とし, 3 反復調査した.

\section{3. 結果}

1）定植作業時間の比較

新規法および慣行法における習熟者および初心 者の定植作業時間の比較を図 5 に示した。

（1）習熟者

新規法は慣行法に比べて，苗の定植時間，ホー ラーによる植穴作成時間㧍よび合計の定植作業時 間が有意に減少した．新規ホーラーによる植穴の 作成は 1 株当たり 1.7 秒，セル成型苗の定植は 5.1 秒を要した。一方, 慣行ホーラーによる植穴の作 成は 1 株当たり 3.1 秒，ポット苗の定植は 7.5 秒 を要した。1株の定植に有した時間は，新規法は 6.7 秒，慣行法は 10.6 秒であった。

(2) 初心者

新規法は慣行法に比べて苗の定植時間，ホー ラーによる植穴作成時間および合計の定植作業時 間が有意に減少した，新規ホーラーによる植穴作 成は 1 株当たり 2.6 秒，セル成型苗の定植は 12.0 秒を要した。一方，慣行ホーラーによる植穴作成 は 1 株当たり 4.1 秒，ポット苗の定植は 33.1 秒 を要した。1株の定植に有した時間は，新規法は 14.6 秒, 慣行法は 37.2 秒であった.

2）OWAS 法を用いた定植作業姿勢の比較

新規法および慣行法における習熟者および初心 者の定植作業姿勢の比較を図 6 および図 7 に示した。 


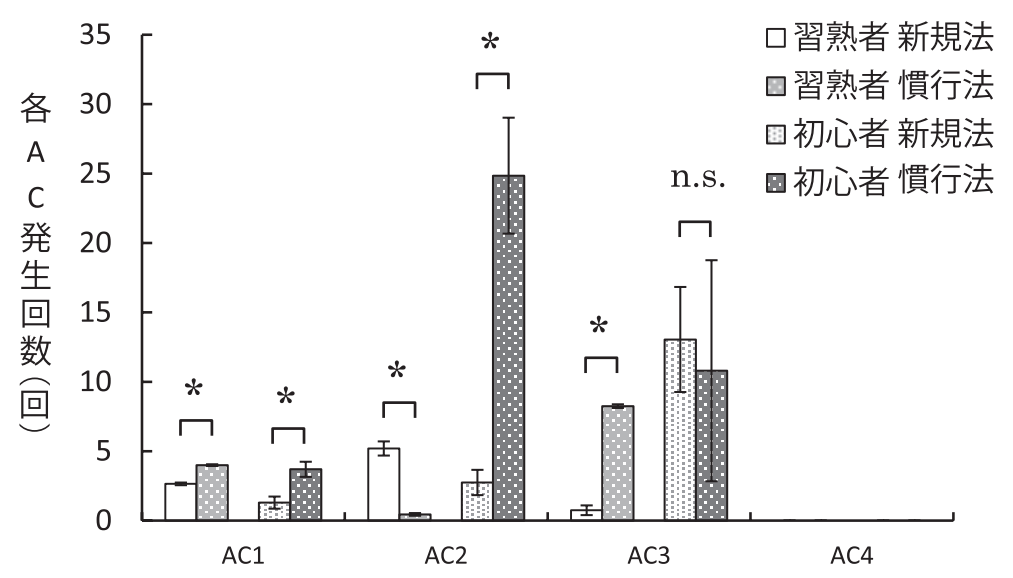

図 7 新規法および慣行法における習熟者および初心者の各 $\mathrm{AC}$ 発生回数 の比較

5 株の定植作業を 1 反復とし, 4 反復調査した $(n=4)$.

エラーバーは標準誤差を示す。

*はU検定において $5 \%$ 水準で有意差あり, n.s. は有意差なしを示す。

\section{（1）習熟者}

新規法および慣行法ともに，ただちに改善す べきとされる作業負担度の $\mathrm{AC} 4$ は発生しなかっ た。新規法では $\mathrm{AC} 2$ の発生割合が最も高く，慣 行法では AC3 の発生割合が最も高かった。でき るだけ早期に改善すべきとされる作業負担度であ る AC3 の発生割合は, 新規法が慣行法に比べて 低かった。発生回数における比較でも，新規法は 慣行法に比べて, AC3 の発生回数は有意に低かっ た、ホーラーによる植穴の作成において，背部で

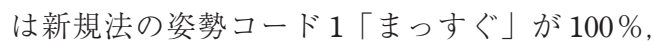
慣行法の 1「まっすぐ」が $98.8 \%$ ，2「前または 後乃に曲げる」が $1.2 \%$ であり，苗の定植では新 規法の 2 「前または後ろに曲げる」が $100 \%$ ，慣 行法の 1 「まっすぐ」が $4.0 \%, 2$ 「前または後ろ に曲げる」が $96.0 \%$ であった ホーラーによる植 穴の作成において，上肢では新規法の1「両腕と も肩より下」が $66.7 \% ， 3 「$ 両腕が肩の高さある いはそれより上」が $33.3 \%$ ，慣行法の 1 「両腕と も肩より下」が $19.8 \%$ ，3「両腕が肩の高さある いはそれより上」が $80.2 \%$ であり，苗の定植で は新規法および慣行法ともに 1 「両腕とも肩より 下」が 100\%であった．ホーラーによる植穴の作 成において，下肢では新規法および慣行法ともに 2 「両脚をまっすぐにして立つ」が 100\%であり， 苗の定植では新規法の 2 「両脚をまっすぐにして 立つ」が $87.4 \%, 4$ 「両滕を曲げて立つか中腰」
が $12.6 \%$, 慣行法の 4 「両膝を曲げて立つか中腰」 が $100 \%$ でった。

(2) 初心者

新規法および慣行法ともに, AC4 は発生しな かった。新規法ではAC3の発生割合が最も高 く, 慣行法では AC2 の発生割合が最も高かった. AC3 の発生割合を比べると, 新規法が慣行法に 比べて高かった，発生回数に扔ける比較では, $\mathrm{AC} 1$ 抢よび $\mathrm{AC} 2$ において有意差が確認されたが, AC3に拈いて有意差は確認されなかった。ホー ラーによる植穴の作成において，背部では新規法

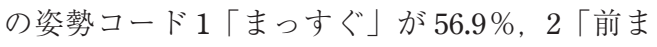
たは後ろに曲げる」が 43.1\%，慣行法の1「まっ すぐ」が $65.2 \% ， 2$ 前または後ろに曲げる」が $34.8 \%$ であり, 苗の定植では新規法の1「まっすぐ」 が $0.8 \% ， 2$ 「前または後ろに曲げる」が $99.2 \%$,

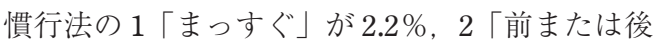
ろに曲げる」が $97.8 \%$ であった，ホーラーによる 植穴の作成に押いて，上肢では新規法の1「両腕 とも肩より下」が $49.0 \%, 3$ 「両腕が肩の高さあ るいはそれより上」が $51.0 \%$, 慣行法の 1 「両腕 とも肩より下」が $29.2 \%, 3$ 「両腕が肩の高さあ るいはそれより上」が $70.8 \%$ であり, 苗の定植で は新規法㧍よび慣行法ともに $1 「$ 両腕とも肩より 下」が $100 \%$ であった，ホーラーによる植穴の作 成において，下肢では新規法の 2 「両脚をまっす ぐにして立つ」が 100\%, 慣行法の 2 「两脚をまっ 
表 1 定植時における苗質の評価

\begin{tabular}{|c|c|c|c|c|c|c|c|c|}
\hline \multirow{2}{*}{ 栽培法 } & \multirow{2}{*}{ 育苗法 } & \multirow{2}{*}{ 茎長（cm） } & \multirow{2}{*}{ 根長 (cm) } & \multirow{2}{*}{ 茎数 (本) } & \multicolumn{2}{|c|}{ 生体重（g） } & \multicolumn{2}{|c|}{ 乾物重（g） } \\
\hline & & & & & 地上部 & 地下部 & 地上部 & 地下部 \\
\hline 新規法 & 200 穴セル & 20.4 & 4.5 & 2.2 & 0.29 & 0.49 & 0.07 & 0.08 \\
\hline 慣行法 & $7.5 \mathrm{~cm}$ ポット & $28.4^{z}$ & 19.8 & 5.4 & 2.23 & 3.52 & 0.57 & 0.58 \\
\hline & $\mathrm{t}_{\text {検定 }}^{y}$ & $*$ & $* *$ & $* *$ & $* *$ & $* *$ & $* *$ & $* *$ \\
\hline
\end{tabular}

${ }^{2}$ 定植時に用いた苗株の苗質を調查した $(\mathrm{n}=5)$. 数值はその平均值を表す、

$\mathrm{y} *$ * $\mathrm{t}$ 検定により $5 \%$ 水準で有意差あり，**は $1 \%$ 水準で有意差ありを示す.

すぐにして立つ」が 95.5\%，4「両膝を曲げて立 つか中腰」が $4.5 \%$ であり, 苗の定植では新規法 の 2 「両脚をまっすぐにして立つ」が $17.4 \%, 4$ 「両 膝を曲げて立つか中腰」が $82.6 \%$, 慣行法の 4 「両 膝を曲げて立つか中腰」が $30.8 \% ， 6$ 「片方また は両方の膝を床につける」が $69.2 \%$ であた。

3）栽培法の違いによる苗質の評価および株養成 量の比較

定植時における苗質の評価の比較を表 1 , 新規 法および慣行法における株養成量の比較を図 8 に 示した。慣行法で用いたポット苗における茎長は $28.4 \mathrm{~cm}$, 根長は $19.8 \mathrm{~cm}$, 茎数は 5.4 本, 生体重 は地上部が $2.23 \mathrm{~g}$, 地下部が $3.52 \mathrm{~g}$, 乾物重は地 上部が $0.57 \mathrm{~g}$ ，地下部が $0.58 \mathrm{~g}$ であった。また, 新規法で用いたセル成型苗に㧍ける茎長は 20.4 $\mathrm{cm}$, 根長 $4.5 \mathrm{~cm}$, 茎数 2.2 本, 生体重は地上部が 0.29 $\mathrm{g}$, 地下部が $0.49 \mathrm{~g}$, 乾物重は地上部が $0.07 \mathrm{~g}$, 地 下部が $0.08 \mathrm{~g}$ であり，定植時における苗質は，い ずれの調査項目においても新規法のセル成型苗が 慣行法のポット苗に比べて有意に小さかった（表 1）。ま，根株の養成段階において，七ル成型苗 の初期生育は達観調査で, 成長した茎葉が通路側 に倒れることがなく真っ直ぐ成長していた，株養 成量は, KOB マルチでは新規法が 264.9 , 慣行法 が311.6であった。一方，グリーンマルチでは新 規法が 320.2 ，慣行法が 380.6 であった， 2 種の 異なるマルチにおいて, 株養成量はセル成型苗を 定植した新規法がポット苗を定植した慣行法に比 べてやや劣る傾向が見られたが，新規法抢よび慣 行法に打ける株養成量に有意差は確認されなかっ た（図 8).

\section{4. 考察}

過去のアスパラガスの作業性に関する研究で

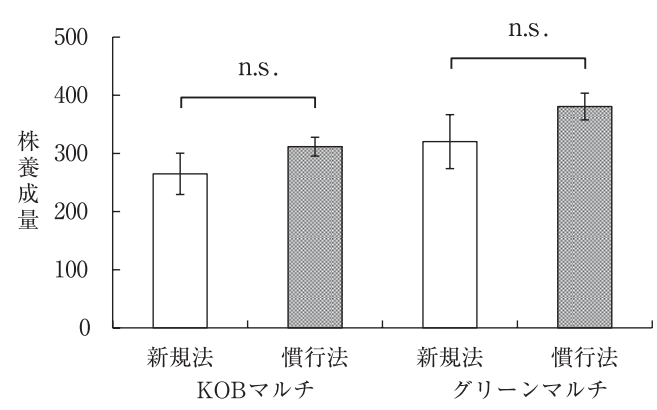

図 8 新規法および慣行法における株養成量の比較 10 株を 1 反復とし, 3 反復調查した $(n=3)$. エラーバーは標準誤差を示す。

n.s. はt 検定において有意差なしを示す。 株養成量 $=$ 根株の生体重 $\times$ 貯蔵根の Brix 值.

は，全期立茎栽培において中腰作業となる若茎収 穫の作業性を評価した報告（坂本ら 2011），およ び作業性の改善のために若茎収穫専用の長柄収穫 ハサミ「アスパラーク」を開発し，その作業性を 評価（坂本ら 2014）した報告がある。また，ア スパラガスの夏秋どりにおいて, 親茎（養成茎） を斜めに誘引し, 収穫可能な若茎の視認性を高め た「母茎地際押し倒し法」と呼ばれる栽培体系が 開発された（坂本ら 2011）。これらのように, 器 具や栽培体系の開発の視点から作業性の改善が可 能である。

本研究は, 新しく開発した新規ホーラーを利用 することより，アスパラガスの定植における作業 性の改善を目的とし, 習熟者 1 名と, 新規就農者 を意識した初心者 1 名を被験者として, 定植作業 の改善効果を調査した。 その結果, 新規ホーラー を利用した新規法は, 慣行法に比べて, 習熟者, 初心者ともに, ホーラーによる植穴の作成時間, 苗の定植時間および定植に関わる全体の作業時間 が有意に減少した。このことから，新規法は，作 
業者の習熟度が異なっても, アスパラガスの定 植作業時間を短縮できることが明らかになった。 この理由としては, 本研究で用いた慣行法の 7.5 $\mathrm{cm}$ 径のポット苗は 1 株当たりの容量が約 $220 \mathrm{~mL}$ であるのに対し，新規法の 200 穴セル成型苗は 1 株当たりの容量が約 $25 \mathrm{~mL}$ とサイズが小さく軽 量になり，苗の持ち運びや定植作業が容易になっ たことが一因として挙げられる。また，慣行法で は慣行ホーラーを地面に突き差し, 畧内の土をつ かんで外に放出することにより植穴を作成するの に対し，新規法では新規ホーラーを直接地面に突 き差す動作のみで植穴を作成できることが，植穴 の作成時間を大きく短縮したものと考えられる. セル成型苗の定植作業時間に関する研究として は，セイヨウカボチャ ‘えびす’を用いたセル成 型苗がポット苗に比べて苗の定植作業時間を短縮 でき，運搬作業を軽減できたという報告がある(杉 山ら 2006)。また, ‘TC2A'におけるセル成型苗 の定植作業時間は，ポット苗に比べて約 $43 \%$ に 短縮され，比較として用いた“えびす’でも同様 に約 46\%に短縮された（辻ら 2011）。本研究のア スパラガスにおいても，新規法におけるセル成型 苗の定植作業時間は，慣行法に㧈けるポット苗の 定植作業時間に比べて習熟者で約 $63 \%$, 初心者 で約 39\%に短縮され，既報（杉山ら 2006, 辻ら 2011）と同様の結果が得られた。

作業姿勢の比較においては, 習熟者が新規法で 定植した場合，慣行法に比べて AC3 の発生割合 が明らかに低くなり，作業負担が軽減されること が明らかになった。この理由としては，滕を大き く曲げずに苗を定植することが可能となったため である，前述のと抢り，七ル成型苗はポット苗に 比べて軽量であることから, 従来のような, しゃ がんでポット苗を定植する作業姿勢ではなく，新 規ホーラーで作成した植穴に対して立ったままの 姿勢でセル成型苗を落とすことにより定植するこ とができる，そのため，習熟者では，定植作業時 間が大幅に短縮され，できるだけ早期に改善す べきとされる作業負担度である AC3 の発生割合 㧍よび発生回数も大きく減少した。一方, 初心者 では, 各 $\mathrm{AC} の$ 発生割合は習熟者と異なり, 新規 法が慣行法に比べて AC3 の割合が高いという結 果となった。この理由としては, 初心者が慣行法 において地面に膝をついて定植作業を行ったた め, AC2 の発生割合および発生回数が増えたこ
とが主な要因として挙げられる。地面に膝をつい た定植作業は, 作業速度が遅く, 多くの定植作業 時間を要したものの, OWAS 法では AC3 に比べ て作業負担が少ない AC2 の作業姿勢に分類され た。そのため, 初心者では, 作業姿勢の解析ソ フトの評価基準上で, AC3 より作業負担度が低 い AC2 が多く発生した。しかし, 発生回数の観 点から評価すると, 新規法では, 慣行法に比べて $\mathrm{AC} 2$ の発生回数が有意に少なく, $\mathrm{AC} 3$ の発生回 数は慣行法と新規法との間に有意差は確認されな かった，加えて，新規法の $\mathrm{AC1} の$ 発生回数㧍よ び合計の $\mathrm{AC}$ 発生回数は慣行法に比べて有意に少 なかったことから（いずれも U 検定で $\mathrm{P}<0.05 ）$, 総合的に見れば, 新規法の方が作業負担は低いも のと考えられる。このように, 新規ホーラーを利 用することにより, 初心者でも同様に作業負担の 軽減効果があることが明らかになった。しかし， 本研究は熟練度の異なる 2 名の被験者のみの調査 であるため, 今後は被験者数を増やして試験を行 うことにより, 新規ホーラーの作業負担の軽減効 果がさらに明確になると考える.

株養成量の比較では, 新規法は慣行法と同等の 株養成量が得られた。また, 2014 年の試験の株 重に招いても, 新規法と慣行法との間に有意差 がなかったという結果が得られている（清水ら 2015a）。既報（酒井ら 1991）では, 株養成量が 若茎の収量に影響するとされることから, 本研究 の株養成量の数值から判断して, 新規法による定 植は, 育苗日数が短い小苗にも関わらず, 株養成 量は慣行法と有意差がなかったため, 実際に収量 調查は行っていないものの, 新規法で定植した場 合も, 慣行法で定植した場合と同等の収量が得ら れる可能性があると考えられる。この理由として は, 新規ホーラーはセル成型苗を $15 \mathrm{~cm}$ 程度の深 植えにすることにより（図 2), 晚霜被害が発生 するような早春期においても低温遭遇の影響が少 なくなり（清水ら 2015b）, 定植直後の生育や根 の活着が順調に進んだ可能性が考えられる.また, セル成型苗の初期生育において, 成長した茎葉が 通路側に倒れることがなく真っ直ぐ成長したため (達観調査), 萌芽が促進されたことも一因として 挙げられる。伏せ込み促成栽培は, 株養成期間を 1 年間とすることが多いが (小泉 2007), 収量を 高めることを目的に大株を養成するため, できる だけ早期に定植し，株養成期間を長くとることが 
重要である（山口ら 2013）。小泉·中條 (2008) は, 8 月に播種して 9 月に定植し, 株養成期間を長く とる 1 年半株養成法を検討し, 1 年半株養成法は 1 年株養成法に比べて若茥の総収量が多いことを 報告した，新たに開発した新規法は，植穴内の保 温効果を有し（清水ら 2015b），その効果によっ て霜害発生の危険がある慣行法では不可能な早期 （早春）定植も実現できる可能性があり，本戋で の株養成期間の延長による株養成量の増大 (多収) 効果も期待できる.

今後は, 新規法に適する, 深植え適性やセル成 型苗直接定植の適性, 耐寒性のある品種の選定, 実際の若茎収量とその品質の検討などを行う必要 がある，また，新規ホーラーにより作成した植え 穴内の温度は, 慣行法に比べて早春期における温 度の低下が緩和された（清水ら 2015b）。さらに, 2 種類の異なるマルチを用いて調査を行ったとこ ろ, 生育に差が認められた（石井ら 2014）こと から, 低温期に地温を確保するためのマルチの色 も今後検討していく必要がある.さらに, 新規ホー ラーの形状や重さなどを改良することにより，さ らなる軽作業化拉よび省力化が可能であると考え られる。

以上の結果, 新規ホーラーによってアスパラガ スの早期定植ができる可能性が示され，七ル成型 苗の直接定植は, アスパラガス伏せ込み促成栽培 において有効であることが示唆された。 今後は伏 せ込み促成栽培以外の他の作型における利用の可 能性についても検討していきたい.ところで，七 ル成型苗の直接定植に関する研究は, キャベッな どの葉菜類や果菜類などでも行われている(根岸. 大島 2009, 山田・大江 1997, 吉岡 2007）ことか ら，今後はアスパラガスだけに限らず，他品目に おいても，新規ホーラーを利用したセル成型苗の 直接定植や, 早期定植による作型前進の可能性を 検討していきたい.

\section{引用文献}

有馬 博·細井克敏・山岡浩一・石黒幸雄（1995）: 開発した加工用トマト小型収穫機の構造と作 業能率, 農作業研究 30 (2)；111-120.

中央農業総合研究センター（1995）：青年によ る農業へのイメージ評価, http://www.naro. affrc.go.jp/project/results/laboratory/narc/1995/ narc95-2-215.html（2015 年 1 月 22 日閲覧）.
藤原隆広・亀井雅浩・熊倉裕史 - 吉田祐子 - 窪田 潤・内藤和男・高田健一郎 (2006) : ホウレ ンソウセル成型苗を利用した移植栽培への電 動型半自動多条移植機導入による労働負担軽 減効果, 農作業研究 41(1)；12-20.

石井葉菜子 - 清水 佑 - 松永邦則 - 浦上敦子 . 山口貴之 · 寺崎 亮 ·池浦博美 ·元木 悟 （2014）：アスパラガス栽培に扮ける早期定 植のためのマルチの色の効果, 園芸学研究 13 (別 2)；459.

石川文武・小林 恭 (1999): 労働科学とエルゴ ノミクス, 日本農作業学会編, 農作業学, 農林 統計協会, 東京, pp. 54-70.

地子 立·志賀義彦·今野一男·田中静幸 (2008)： 伏せ込み促成栽培に扮ける遮光フィルム資材 を用いたホワイトアスパラガス生産, 園芸学 研究 7(2)；241-247.

地子 立 - 午来 博 - 中野英樹 - 市川伸次 - 松永 邦則·三浦信一・杉原雄一・荒木 肇 (2011): 北海道に扔けるグリーンアスパラガス伏せ 込及促成栽培の品種特性, 園芸学研究 10 (別 2)；430.

金子賢一・鈴木雅人（2002）：抑制トマトのセル 成型苗直接定植栽培に扮ける側枝 2 本仕立 てが生育・収量・果実品質に及ぼす影響, 茨 城県農業総合センター園芸研究所研究報告 $10 ; 8-14$.

Karhu, O., Kansi, P. and Kuorinka, I. (1977): Correcting working postures in industry: A practical method for analysis, Applied Ergonornics 8(4); 199-201.

Karhu, O., Haerkoenen, R., Soevali, P. and Vepsaelaeinen, P. (1981): Observing working postures in industry: Examples of OWAS application, Applied Ergonornics 12 (1) ; 13-17. 北澤裕明·元木 悟·山崎 篤・浦上敦子 (2012) : アスパラガスの 1 年株における貯蔵根 Brix 值測定法の提案, 根の研究 21(1)；11-16.

小泉丈晴（2007）：アスパラガスの生理生態と栽 培技術, 第 7 回 伏せ込み促成栽培, 農耕と園 芸 62 (10)；176-181.

小泉丈晴・中條博也（2008）：伏世込み促成アス パラガス栽培における 1 年半株養成法が茎枯 病発生, 根株および若茎の生育に及ぼす影響, 群馬県農業技術センター研究報告 5 ；44-45. 
前川寛之・桐山晴美・黒住 徹 (2000）：農作業 の軽作業化に関する人間工学的研究,イチゴ 栽培における栽培面の高さと作業姿勢につい て, 奈良県農業試験場研究報告 $31 ; 1-8$.

皆川裕一 - 元木 悟 - 園田高広 - 浦上敦子 - 甲村 浩之・池内隆夫·北澤裕明・松永邦則 (2013)： 世界のアスパラガス生産の現状と展望〔21〕 21. 国内および海外の品種動向と今後の方向 性, 農業㧍よび園芸 88(9)；927-938.

宮菩朋浩・片岡正登（2004）：イチゴ栽培システ ムに打ける作業姿勢に基づく農作業の労働負 荷測定㧍よび評価法の確立, 長崎県総合農林 試験場研究報告 農業部門 $30 ； 29-39$.

元木 悟 (2003) : アスパラガスの作業便利帳, 農 山漁村文化協会, 東京, pp. 12-28.

元木 悟 - 西原英治 · 北澤裕明 - 平舘俊太郎 - 藤 井義晴・篠原 温（2006）：アスパラガス連 作障害に打けるアレロパシー回避のための活 性炭の利用, 園芸学研究 5(4)；437-442.

元木 悟（2008）：アスパラガスの高品質多収技 術, 元木 悟 - 井上勝広 - 前田智雄編, 農山漁 村文化協会, 東京, pp. 131-135.

根岸直人・大島一則（2009）：トマトの促成長期 どり栽培におけるセル成型苗直接定植法, 栃 木県農業試験場研究成果集 $27 ; 14-15$.

農林水産省 (2006)：第 6 節 作業環境改善, み やぎの野菜指導指針, pp. 320-329, http://www. maff.go.jp/j/seisan/kankyo/hozen_type/h_sehi kizyun/pdf/miyagi_yasai18_25.pdf（2015 年 1 月 22 日閲覧).

農林水産省 (2009)：平成 20 年度 食料 ·農林 水産業・農村漁村に関する意向調査 高齡農 業者の営農や地域活動への参画に関する意向 調査結果, p 6, http://www.maff.go.jp/j/finding/ $\operatorname{mind} /$ pdf/20090311_enquete1.pdf (2015 年 1 月 22 日閲覧).

農林水産省（2013）：農家人口, 農業就業人口, 基 幹的農業従事者数の推移, (2) 農家戸数, 農 業就業人口, 農地等, 2 農業経済の動向, 第 2 部, 平成 25 年度版 食料・農業・農村白書 参考統計, 農林水産省編, 東京, p 114.

農林水産省大臣官房統計部 (2014)：平成 25 年度 新規就農者調査, 農林水産統計, pp. 1-2, http:// www.maff.go.jp/j/tokei/kouhyou/sinki/pdf/sinki syunou_13.pdf（2015 年 1 月 22 日閲覧）.
大石 毅・與座一文・屋良利次 - 棚原尚哉・宮 城聡子 - 伊志嶺弘勝 - 伊山和彦 - 小禄博昭 (2010) : トゥガン (Benincasa hispida (Thunb.) Cogn）の立体栽培と地這い栽培における収 量と作業姿勢の比較, 沖縄県農業研究セン ター研究報告 $4 ; 32-35$.

坂本隆行 - 越智資泰·田中昭夫·今井俊治 (2011): アスパラガス全期立茎栽培における“母茎地 際押し倒し法”が収量と収穫作業性に及ぼす 影響, 園芸学研究 10(3)；375-382.

坂本隆行 - 越智資泰 - 菊池 豊 - 小林 恭 - 田中 亨・尾崎行生（2014）：アスパラガス全期立 茎栽培における側枝誘引法の検討と長柄収穫 八サミ利用による作業性改善効果, 園芸学研 究 13(別 2)；164.

酒井 亨・丸山 進・小沢智美 (1991)：アスパ ラガス促成栽培に扔ける収量構成要因の解明 （第 7 報）促成栽培株の評価基準, 園芸学雑誌 60 (別 2)；374-375.

沢田英一・羽根 義 (2002)：OWAS 法による建 設作業負担の評価, 人間工学 38 特別号 ; 522 523.

瀬尾明彦 (1995)：OWAS：Ovako 式作業姿勢分析 システム, http://www.nrec.sakura.ne.jp/OWAS. $h t m$ (2015 年 1 月 22 日閲覧).

渋川 洋・井上明大 ·姫野修司・小松俊哉 (2014)： 下水污泥と稲わらの混合嫌気性消化によるバ イオガス生産に向けた稲わら収集・運搬体系 の検討一新潟県長岡地域に扮ける事例一, 農 作業研究 49(2)；69-78.

清水 佑 - 石井葉菜子 - 松永邦則 - 浦上敦子 - 山 口貴之・池浦博美・元木 悟 (2015a) : アス パラガスの伏せ込み促成栽培に扔ける早期定 植の検討, 園芸学研究 14 (別 1)；360.

清水 佑・松永邦則・元木 悟 $(2015 b)$ : アスパ ラガス伏せ込み促成栽培における新たに開発 したホーラーを用いた作業性改善効果, 農作 業研究 50(別 1)；19-20.

杉山 裕 - 長尾明宣 - 中野雅章 (2006)：セル成 型苗定植栽培がセイヨウカボチャ(「えびす」) の収量性, 着果性抢よび作業省力性に与える 影響, 北海道立農業試験場集報 $90 ； 61-64$.

但馬県民局（2012）：農業新 $3 \mathrm{~K}$ を目指すシンポ ジウムの開催一但馬農業を稼げて・感動あっ て・かっこよく-, http://web.pref.hyogo.lg.jp/ 
governor/documents/g_kaiken20120604_08.pdf (2015 年 1 月 22 日閲覧).

Takala, R. P. and Kukkonen, R. (1987): The handling of patients on geriatric wards : A challenge for on-the-job training, Applied Ergonornics 18(1)；17-22.

武田 悟・本庄 求 (2005): 促成アスパラガス 養成株の掘り取り時期の判定, 東北農業研究 $58 ; 189-190$.

辻 博之 · 村上則幸 - 杉山慶太 - 杉戸智子 - 嘉 見大助・大下泰生 (2011) : 短節間カボチャ 'TC2A'のセル成形苗機械定植栽培による作 業の省力化, 農作業研究 46(2)；59-67.

山田幸信・大江せき也（1997）：メロンのセル成 型苗の実用化, 石川県農業研究成果集 $9 ； 10$ 11.

山口貴之 ·元木 悟 - 小泉丈晴 - 松永邦則 - 渡辺 慎一・前田智雄・浦上敦子・荒木 肇 (2013)： 世界のアスパラガス生産の現状と展望〔17〕 17. 日本特有の「伏世込み促成栽培」に㧍け る現状と今後の方向, 農業㧍よび園芸 88(5)； 571-578

八巻良和 - 藤多健史 ·佐藤 健 - 宮崎正已 - 野呂 影勇（1993）：平棚とY 字形棚のブドウにお ける作業姿勢の考察, 人間工学 $29 ; 312-313$.

Yin Yin, N., Toyama, S., Akagawa, M., Yamada, M., Sotta, K., Tanzawa, T., Kikuchi, C. and Ogiwara, I. (2012) : Workload assessment with ovako working posture analysis system (OWAS) in japanese vineyards with focus on pruning and berry thinning operations, Journal of the Japanese Society for Horticultural Science 81 (4) ; 320-326.

吉岡 宏 (2007): 植物の根に関する諸問題〔163〕 一キャベッセル成型苗の定植後の根系発達 とセル形状による制御一, 農業および園芸 82 (2) ; 312-315.

\section{Abstract}

We have developed a new hole-maker to plant plug seedlings (grown in cell tray) directly in fields instead of larger pots. In the present study on the forcing cultivation of asparagus, a survey was conducted to examine increases in the efficiency of planting plug seedlings directly in fields using the above-mentioned hole-maker (new method), when compared to the efficiency of planting pot seedlings using a conventional hole-maker (conventional method), and assess the growth amount- an index of the yield. The time required for both inexperienced and experienced growers to plant asparagus using the new method was significantly shorter than that based on the conventional method. Postures during planting were also assessed using an OWAS method based on the frequency and rate of action categories (AC), and the level of improvement in the postures of experienced growers while planting asparagus using the new method was significantly higher compared to when the conventional method was adopted. While there was no increase in the frequency of $\mathrm{AC}$ when asparagus was planted by inexperienced growers, there was an increase in the number of $\mathrm{AC}$. A shorter time was required to plant asparagus, which suggests that the burden of planting using the new method on inexperienced growers is less than that when the conventional method is used. Although the plug seedlings used for the new method were smaller than the pot seedlings used for the conventional method, there were no significant differences in the growth amount of root stock between the two methods in autumn. Therefore, the same asparagus yield can be obtained using the new method and conventional method.

\section{Key Words}

Asparagus officinalis L., hole-maker, planting, plug seedling, workability 